\title{
OPTIMIZATION OF MECHANICAL STRENGTH AND MICROSTRUCTURE ON AUSTEMPERING ZINC HEAT TREATMENT IN LATERITIC NICKEL STEELS
}

\author{
Satrio Herbirowo ${ }^{1}$, Setyo Hartadi ${ }^{2}$, Rahmat D. Widodo ${ }^{2}$ and Bintang Adjiantoro ${ }^{1}$ \\ ${ }^{1}$ Pusat Penelitian Metalurgi dan Material - LIPI \\ Kawasan Puspiptek 15314, Tangerang Selatan \\ ${ }^{2}$ Jurusan Teknik Mesin, Fakultas Teknik - Universitas Negeri Semarang \\ Jalan Taman Siswa Sekaran, Gunungpati Semarang, 50229 \\ E-mail: satr006@lipi.go.id
}

Received: 25 Maech 2019

Revised:7 June 2019

Accepted: 21 June 2019

\begin{abstract}
OPTIMIZATION OF MECHANICAL STRENGTH AND MICROSTRUCTURE ON AUSTEMPERING ZINC HEAT TREATMENT IN LATERITIC NICKEL STEELS. The development of lateritic steel is currently being discussed by various research institutions. It is not separated from the potential of laterite-based steel into national steel. This research using austempering heat treatment process with holding time variation for 30, 60, and 90 minutes with $\mathrm{Zn}$ (Zinc) element from melting ingot with $90 \%$ purity for cooling media. The characterization of laterite steel is done by hardness testing, impact resistance, microstructure, scanning electron microscopy, and energy dispersive spectroscopy. The results showed that the impact resistance value decreased $8.46 \%$, which was initially $209 \mathrm{~J}$ to $191.3 \mathrm{~J}$. Besides, the hardness value increased $36,58 \%$ of which was originally $164 \mathrm{HV}$ to $224 \mathrm{HV}$. Judging from its physical properties, the microstructure formed bainite ferrite perlite at holding time 90 minutes while the fracture is included into the ductile fracture because there are dimple holes showed dark and opaque.
\end{abstract}

Keywords: Lateritic steel, Austempering, Impact resistance, Microstructure.

\begin{abstract}
ABSTRAK
OPTIMALISASI SIFAT KEKUATAN MEKANIK DAN STRUKTUR MIKRO PADA PERLAKUAN PANAS AUSTEMPERING ZINC PADA BAJA NIKEL LATERIT. Pengembangan baja laterit saat ini menjadi perbincangan oleh berbagai lembaga penelitian. Hal tersebut tidak lepas dari potensi baja berbasis laterit menjadi baja nasional. Penelitian ini menggunakan proses heat treatment austempering dengan variasi holding time austempering selama 30, 60, dan 90 menit serta menggunakan media pendingin unsur Zn (Zinc) dari lelehan ingot dengan kemurnian $90 \%$. Karakterisasi baja laterit yang dilakukan dengan pengujian kekerasan, ketahanan impak, struktur mikro, scanning electron microscopy energy dispersive spectroscopy, Hasil penelitian menunjukkan nilai ketahanan impak tertinggi pada waktu tahan 30 menit austempering zinc dengan nilai impak247,6 J. Disamping itu nilai kekerasannya meningkat 36,58 \% dari yang awalnya $164 \mathrm{HV}$ menjadi 224 HV. Dilihat dari sifat fisisnya, struktur mikro yang terbentuk bainit ferit perlit pada holding time 90 menit sedangkan untuk hasil patahannya termasuk kedalam patahan ulet karena terdapat lobang-lobang dimple dan berpenampilan buram atau gelap.
\end{abstract}

Kata kunci: Baja laterit, Heat treatment Austempering, Ketahanan impak, Strukturmikro.

\section{INTRODUCTION}

Lateritic steel is the result of the acquisition of laterite nickel ore which is used as an alloy in the manufacture of high strength steel, the application of superalloys and alloy metals to increase corrosion resistance $[1,3]$. With an iron content of $35-45 \mathrm{wt} \%$ and nickel $0.8-1.5 \mathrm{wt} \%$ in the laterite nickel ore, after extraction 
and pyometallurgy into Nickel Pig Iron (NPI), it will support steel production with nickel alloy content reaching $2-3 \%[2]$.

In the previous study explained that the austempering process was a method that could possibly replace quench and tempering in the treatment of SAE 8620,4320 and 8822 steels because this process can reduce distortion and be more economical [4]. Mechanical properties are influenced by the time of austempering can increase the hardness and impact toughness of AISI 4340 steel. In the previous research, austempering process on nodular cast iron has been carried out with variation and time in holding temperature in the furnace which produces a phase in microstructure in the form of bainite and residual austenite [5].

To deep explore the potential of lateritic steel, one of the researches will be carried out through austempering heat treatment process. With austempering holding time variation and characterization performed. In the austempering process, holding temperature of about $320-550{ }^{\circ} \mathrm{C}$ requiring immersion medium that does not undergo evaporation in the temperature region to obtain lower bainite [6]. In this research, austempering cooling media is renewed using ingot Zinc ( $\mathrm{Zn}$ ) which has a melting point of $419{ }^{\circ} \mathrm{C}$ with the hypothesis that a laterite steel sample can form a bainite phase referring to the CCT diagram of $0.2 \%$ carbon element and aims to evaluate the effect of holding time variations on the process austempering heat treatment on mechanical properties and microstructure and fracture forms laterite nickel steel.

\section{EXPERIMENTAL METHOD}

\section{Materials and Instruments}

In this research the material used is nickel lateritic steel products from the casting and converting process carried out at the Research Center for Metallurgical Research and Materials of the Indonesian Institute of Scences with a $100 \mathrm{Kg}$ capacity induction furnace and heating up to $1650^{\circ} \mathrm{C}$. The composition of nickel laerite steel was tested by spectroscopy with the results in Table 1.

Table 1. Chemical composition of Lateritic nickel steels

\begin{tabular}{ccccccccc}
\hline Element & $\mathrm{C}$ & $\mathrm{Si}$ & $\mathrm{Mn}$ & $\mathrm{P}$ & $\mathrm{S}$ & $\mathrm{Cr}$ & $\mathrm{Ni}$ & $\mathrm{Fe}$ \\
\hline $\mathrm{wt} \%$ & 0,2 & 0.2 & 0,3 & 0,01 & 0 & 0,4 & 1.5 & $\mathrm{Bal}$ \\
\hline
\end{tabular}

The process equipment used in the research includes induction furnaces for raw material melting, muffle furnaces for heat treatment processes and Precicutting for sample preparation referring to testing standards including Vickers hardness testing, impact resistance with ASTM E23 05 standard using CMTS impact testing model CI-30 model, to determine phase microstructure formed using Meiji techno metallurgical microscope MT7100 and fracture observation using SEM JEOL JSM-6390A.

\section{Methods and Procedure}

Plate-shaped lateritic nickel steel prepared by the formation of standard impact testing samples using cutting and milling machines and EDM for the formation of a $45^{\circ} \mathrm{v}$-notch angle. Then the sample was carried out by heat treatment process with the austempering method which required two temperature, for example by heating the austenization temperature of $950{ }^{\circ} \mathrm{C}$ and then being held for 60 minutes on the first furnace. In the second furnace using a temperature of $450{ }^{\circ} \mathrm{C}$ with melted zinc element cooling media and a variation of the holding time for 30,60, and 90 minutes. The cooling media used is liquid metal. As used in this study, zinc ( $\mathrm{Zn})$ metal with a purity of $90 \%$, has a melting point at $692 \mathrm{~K}$ and a vapor point of $1180 \mathrm{~K}$ which acts as maintaining the tempering temperature in producing the bainite phase. Furthermore, the hardness test Vikers, charpy impact test on the sample after the heat treatment and the characterization of the microstructure and fracture morphology using optical metallography and SEM-EDS.

\section{RESULTS AND DISCUSSION}

\section{The Result of Hardness Test with variety of Holding Time}

The data from the hardness test results on austempering heat treatment process samples increased the value of the hardness that increase significantly. The data obtained from the Vickers hardness testing on variety of holding time at 0, 30,60 and 90 minutes.

From Figure 1, it can be seen that the highest hardness value is produced in a variation of 90 minutes holding time which reaches $224 \mathrm{HV}$, this result increases $36.58 \%$ for raw material samples this occurs because of the structure of bainite and chrome carbide formed by the presence of alloys $\mathrm{Cr}$ [7]. Where the structure of bainite according to Totten, has a hardness value above the ferrite-pearlite structure which on average only has

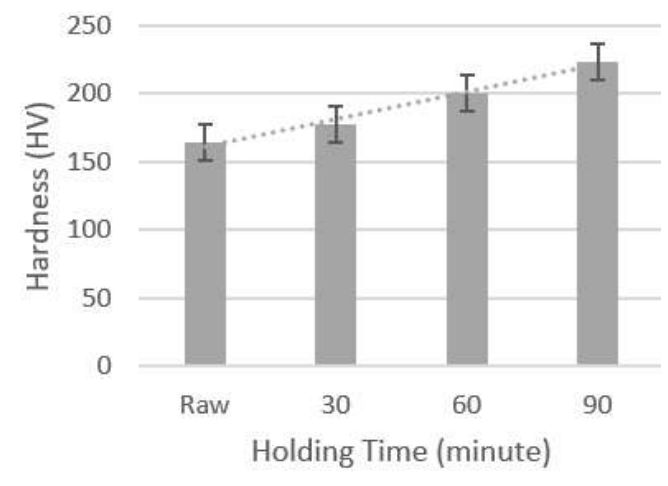

Figure 1. Hardness test results 
a hardness value of $70 \mathrm{HV}-150 \mathrm{HV}$, but the hardness does not exceed the martensitic structure which can reach an average of $400 \mathrm{HV}-513 \mathrm{HV}$ [8].

\section{The Result of Impact Strength Test with variety of Holding Time}

The data obtained from the charpy impact test on variations in holding time 0 minutes, 30 minutes, 60 minutes, and 90 minutes were $209 \mathrm{~J}, 247.6 \mathrm{~J}, 194 \mathrm{~J}$, and $191.3 \mathrm{~J}$.

It can be seen in the impact test results that the highest impact resistance value occurs at a time variation of 30 minutes which reached $247.6 \mathrm{~J}$ or increased by $18.46 \%$ for raw material samples, this occurs because the finer ferrite-pearlite structure is formed and proves that phase transformation ferrite-pearlite into bainite has begun to appear. Whereas the material with a 60 minute holding time has decreased the impact resistance value to $194 \mathrm{~J}$ or a decrease of $7.17 \%$ for the raw material as well as the sample holding time of 90 minutes decreases the impact resistance value produced which reaches $191.3 \mathrm{~J}$ or decreases by $8,46 \%$ of raw material. This is largely related to the increase in the value of violence, making the sample more brittle. Based on Figure 2, it can be seen that the longer the holding time or holding time lasts, the energy that can be absorbed by the test material decreases due to the increasing number of bainite structures formed. In previous research [9] the longer the holding time of austempering it will decrease the level of toughness because the formation of bainite structures above $20 \%$ more homogeneous which will cause the level of material hardness to rise and reduce the level of toughness of laterite steel material.

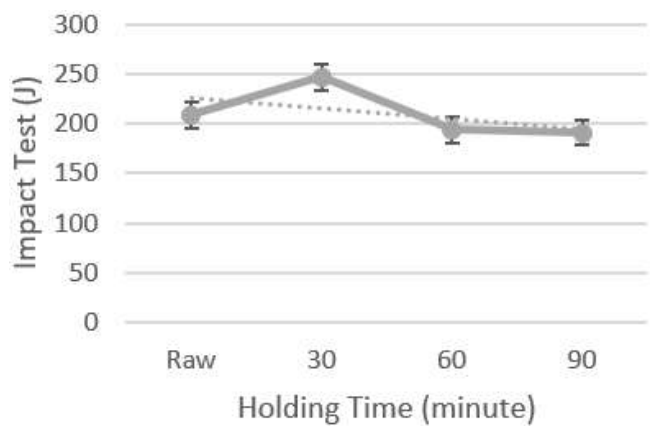

Figure 2. Impact Test Result

\section{Metallography}

Metallographic analysis with 200 and 500x magnification in austenitizing temperature sample of $950^{\circ} \mathrm{C}$ with a temperature of $30 ; 60$; and 90 minutes in the form of Figure 3 (a) confirmed that laterite steel has a micro structure in the form of ferrite and pearlite as a result of casting. For figure 3 (b) steel microstructure in the form of pearlite ferrite with fine grains then Figure 3
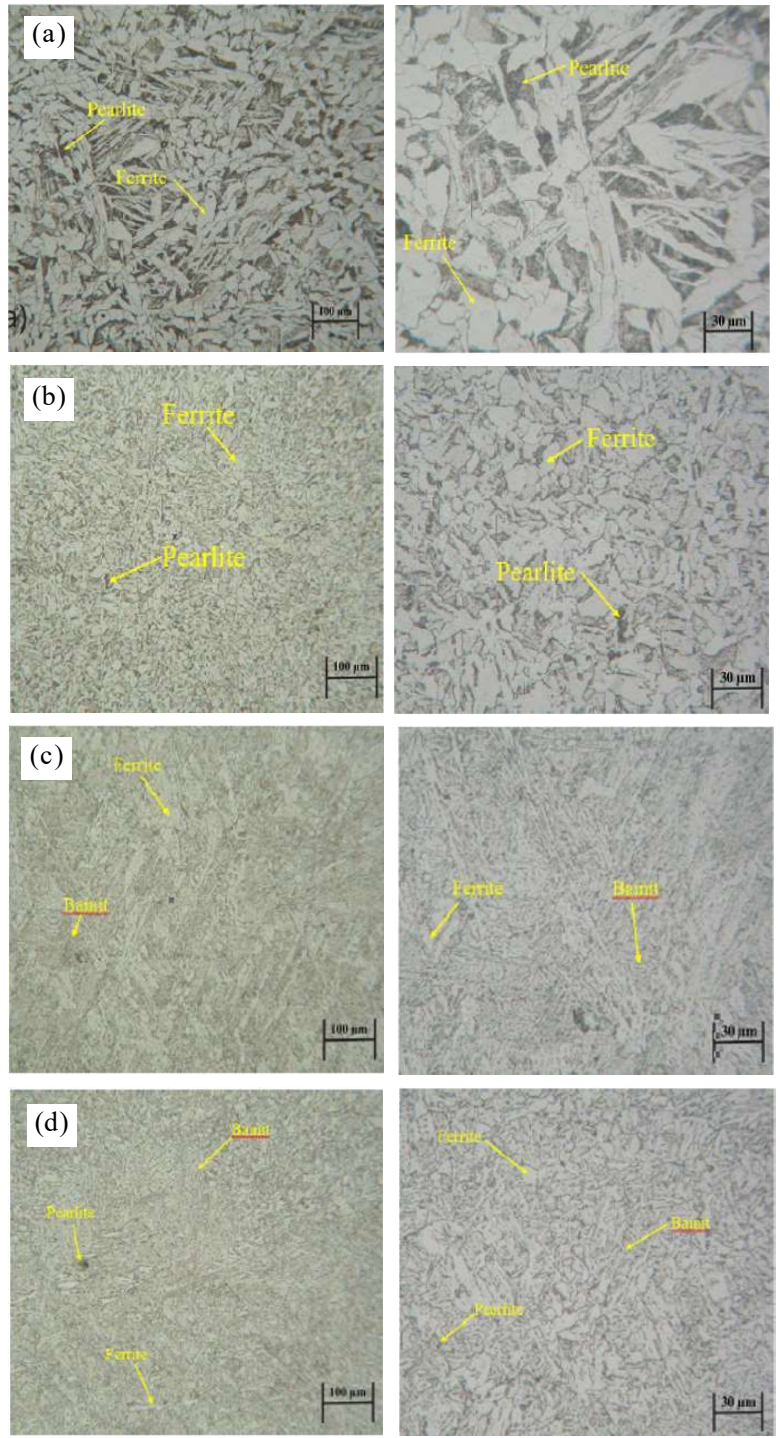

Figure 3. Metallographic results with a magnification of 200 and 500x in austenisation sample temperature of $950^{\circ} \mathrm{C}$ with a temperature resistant a) raw material b) 30 minutes c) 60 minutes d) 90 minutes

(c) has a micro structure in the form of pearlite ferrite bainite matrix plate shape and in Figure 3 (d) the microstructure is a pearlite ferrite bainite matrix. From Figure 3, metallographic testing shows that the holding time variation in the heat treatment austempering process affects the microstructure of the steel. The longer holding time, the more bainite structure is formed, and vice versa, ausferrite transformation occurs, namely the dominant ferrite phase which softens laterite steel [10].

Figure 3. Specimens with heat treatment austempering at a 30 minute holding time still have ferritepearlite microstructure but already have a fine grain shape it is evident that the transformation process of the austenite phase to bainite has occurred, but with a holding time of only 30 minutes it is not clear the phase formation bainit, while at holding time 60 and 90 minutes the microstructure of bainite has begun to be seen because the phase transformation from austenite to 
bainite has already entered the upper and lower bainite regions.

From the content of $\mathrm{Ni}$ which has a weight percent of $1.564 \%$, nickel which dissolves in ferrite forms a fcc unit cell (austenite stabilizer) and decreases the eutectoid temperature. Ferrite-soluble nickel increases toughness, decreases 50\% $\left({ }^{\circ} \mathrm{C}\right)$ of Fracture Appearance Transition Temperature (FATT), even subzero temperature [9].

\section{Fractography}

SEM testing aims to see the type or form of fault formed in raw materials and materials with a heat treatment austempering process for further analysis.

The resulting fracture in each material both raw material and after the heat treatment process is included in the type of ductile fault, as seen from the highest hardness value obtained only $224 \mathrm{HV}$ and the impact resistance value only reaches $247.6 \mathrm{~J}$, the value is still classified as the type of fault resilient, can be seen from the phase formed is the bainite phase which has a multidimple form [11], but there is no martensite phase which has brittle fracture results because it has a high hardness value and low impact resistance value. Each sample provides stringent characteristics (fibrous frature) which involves a shifting mechanism of the crystal field in a ductile metal and absorbs light and dull or dull appearance. small cavity during loading.
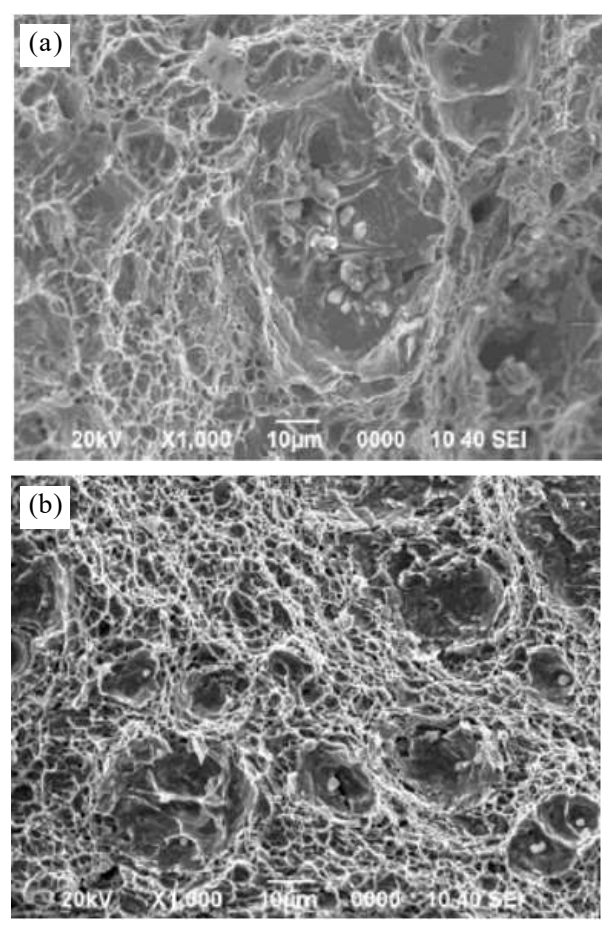

Figure 4. Fractograph test results with SEM a) raw material b) heat treated

\section{CONCLUSION}

The conclusion of the research that has been done is that there is an increase in the hardness after austempering zinc from $164 \mathrm{HV}$ to $224 \mathrm{HV}$ or an increase of $36.58 \%$ while the impact strength has an effective increase in holding time of 30 minutes with an impact value as large as $247.66 \mathrm{~J}$.

The variation of holding time affects the microstructure of laterite steel. The microstructure transformation from raw material which initially has a ferrite pearlite phase transforms into a finer pearlite ferrite phase. Particularly in the austemper treatment the holding temperature of 60 and 90 minutes shows the bainite phase even though there is still a pearlite ferrite phase and this can also be seen from the fracture impact test which forms a ductile fracture of dimple holes as a result of the process of joining small cavities during loading.

\section{ACKNOWLEDGEMENT}

The author expressed his gratitude to the Metallurgical Research Center and the LIPI Material who facilitated the research and testing process and collaborated with mechanical engineering department of Semarang state university

\section{REFERENCES}

[1]. Saefudin, T. B. Romijarso, and D. P. Malau, "Pembuatan Struktur Dual Phase Baja Aisi 3120H Dari Besi Laterit," no. November, pp. 1-5, 2016.

[2]. P. Prasetiyo, "Tidak sederhana mewujudkan industri pengolahan nikel laterit kadar rendah di Indonesia sehubungan dengan Undang-Undang Minerba 2009," J. Teknol. Miner. dan Batubara, vol. 12, no. 3, pp. 195-207, 2017.

[3]. M. Yunan Hasbi, D. Panghihutan Malau, and B. Adjiantoro, "Pengaruh Variasi Reduksi Terhadap Kekerasan dan Struktur Mikro Baja Laterit Melalui Pengerolan Panas," Pros. Semin. Nas. Sains dan Teknol., no. November, pp. 1-8, 2016.

[4]. A. D. Clark, D. O. Northwood, R. J. Bowers, X. Sun, P. Bauerle, and C. G. Llc, "Comparison of Austempering and Quench-and-Tempering Processes for Carburized Automotive Steels," SAE Int. J. Mater. Manuf., vol. 6, no. 2, pp. 146-153, 2013.

[5]. N. Niazi, S. Nisar, and A. Shah, "Austempering Heat Treatment of AISI 4340 Steel and Comparative Analysis of Various Physical Properties at Different Parameters," Int. J. Multidiscip. Sci. Eng., vol. 5, no. 10, pp. 6-11, 2014.

[6]. X. Han et al., "Austenite-Bainite Transformation Kinetics in Austempered AISI 5160 Steel," Eur. Sci. $J .$, vol. 14, no. 12, pp. 1-14, 2018.

[7]. Franco Dwiky Praguna, M. S. Anwar, E. Mabruri, and Sunardi, "KETAHANAN IMPAK, KEKERASAN DAN STRUKTURMIKRO DENGAN VARIASI SUHU PERLAKUAN PANAS Hasil Uji Kekerasan dengan Variasi Suhu 
Austenisasi dan Suhu Tempering," J. Sains Mater. Indones., vol. 19, no. 3, pp. 125-130, 2018.

[8]. G. E. Totten, "Steel Heat Treatment," Steel Heat Treat. Handb., 2006.

[9]. S. Herbirowo, B. Adjiantoro, and F. Citrawati, "Karakteristik Sifat Mekanik dan Strukturmikro Baja Laterit Paduan Ni-Cr-Mn Hasil Tempa Panas Dengan Variasi Beban Tempa," Maj. Metal., vol. 1, pp. 35-42, 2018.
[10]. B. V. de Souza, T. M. Ribeiro, A. Francois, and C. A. dos Santos, "Austempering heat treatments of ductile iron using molten metal baths," Mater. Manuf. Process., vol. 33, no. 15, pp. 1-7, 2018.

[11]. S. Herbirowo, L. Hakim, and B. Adjiantoro, "Microstructure and mechanical characteristics of hot forged lateritic steels," MATEC web Conf., vol. 204, no. 05007, pp. 1-6, 2018. 